\title{
Structural Behavior of Lightly Reinforced Shear Walls of Tunnel Form Buildings
}

\author{
S. Bahadır Yüksel
}

\begin{abstract}
The tunnel-form system has become a primary construction technique in building industry of Turkey as well as in many European countries. In these buildings, all the vertical load-carrying members are made of shear-walls, and floor system is flat plate. Both gravity and lateral loads are transferred to shear-walls. Despite their frequent applications, there is lack of experimental studies to understand the response of the shear walls of tunnel form buildings under extreme lateral loading conditions. In this study, experimental investigation on the inelastic seismic behavior of the shear walls of tunnel form buildings (i.e., box-type or panel systems) is presented. The test was carried out on full-scale rectangular shear wall specimen. The experimental program involves static testing of shear walls having mesh reinforcements under increasing lateral monotonic loading of shear wall specimen. The experimental results indicate that lightly reinforced structural walls of tunnel form buildings may exhibit brittle flexural failure under seismic action. This failure mechanism is of particular interest in emphasizing the mode of failure that is not routinely considered during seismic design of shear-wall dominant structural systems. This type of failure takes place due to rupturing of longitudinal reinforcement without crushing of concrete, therefore is of particular interest in emphasizing the mode of failure that is not routinely considered during seismic design of shear-wall dominant structural systems.
\end{abstract}

Index Terms-Reinforced concrete, seismic design, shear-wall, shear-wall dominant buildings.

\section{INTRODUCTION}

Tunnel form building system is an industrialized construction technique in which structural walls and slabs of the building are cast in one operation by using steel forms having accurate dimensions and plain surfaces [1], [2]. Tunnel form buildings diverge from other conventional reinforced concrete structures with lack of beams and columns in their structural integrity. All the vertical members are made of shear walls and floor system is flat plate. These structures utilize all wall elements as primary load (wind and seismic as well as gravity) carrying members and vertical and lateral loads are distributed homogeneously to the foundation [3].

In tunnel form construction, in situ concrete is poured into two half-tunnel forms to form shear walls and floor slabs simultaneously. When this process is repeated, usually in a

Manuscript received May 24, 2013; revised July 10, 2013. This study was supported financially by Selcuk University BAP (project no: 11401018). The writer wish to express his sincere gratitude to the Selcuk University BAP 11401018 .

S. Bahadır Yüksel is with the Department of Civil Engineering, Engineering Faculty, Selcuk University, Konya, 42075, Turkey (e-mail: sbyuksel@selcuk.edu.tr).
$24 \mathrm{hr}$ cycle per floor, the residential units can be created with great rapidity [4]. In general, all the floor plans become the same due to the same steel tunnel forms being utilized in all of the stories. This construction technology provides great advantages over conventional construction systems, by eliminating use of scaffolding, plastering and simplifying certain operations of placement and striking of formwork as well as installation of reinforcements. The system as a whole, allows for a better organization of the construction activities enabling continuous flow of work, and a higher quality standard. The majority of multi-unit housing, single-family residences, high-rise apartment buildings, hotels, townhouses and warehouses recently constructed in Turkey utilize the tunnel-form system because of its industrialized modular construction technique and repetitive forming features [5], [6].

When destructive earthquakes happen, brittle failure is not desired to occur at the tunnel form buildings in which both lateral and vertical loads are assigned to shear walls [7]-[8]. Strength and ductility requirements must be satisfied considering the seismic design philosophy. The ductility required for energy dissipation is closely related with the reinforcement detailing of shear walls [9]. Results of this study indicate that structural walls of tunnel form buildings may exhibit brittle flexural failure under lateral loading, if they are not properly reinforced. In this study, experimental work on the seismic behavior of the shear walls of tunnel form buildings is presented. Monotonic testing was performed on reinforced concrete shear-wall specimen designed and detailed according to the provisions of the Seismic Code of Turkey [10]. Full scale shear wall of the building specimen were tested under monotonically increasing lateral loading.

\section{DetaIls OF TeSt SPECIMENS AND EXPERIMENTAL PROCEDURE}

The experimental work described herein involves the testing of a full scale shear wall. The test specimen was designed to represent the lower stories of structural walls in high-rise tunnel form buildings. Testing program consisted of monotonically increasing lateral loading. Shear wall specimen was designed and labeled as SW1. The wall was $3.2 \mathrm{~m}$ tall, $1.4 \mathrm{~m}$ length, and $0.2 \mathrm{~m}$ thickness and had an aspect ratio (height-to-width ratio) of 2.285 . The dimension of the elevation view of the shear wall specimen is illustrated in Fig. 1. The wall was located on the building perimeter next to a stairway shaft. The applied gravity loads produced a compressive stress of $1 \%$ of the nominal concrete compressive strength and were therefore ignored in the test program. A detailed description of the experiments and a 
compilation of all test data are available elsewhere [11].



Fig. 1. Elevation view of the reinforcement layouts of foundation and shear-walls.

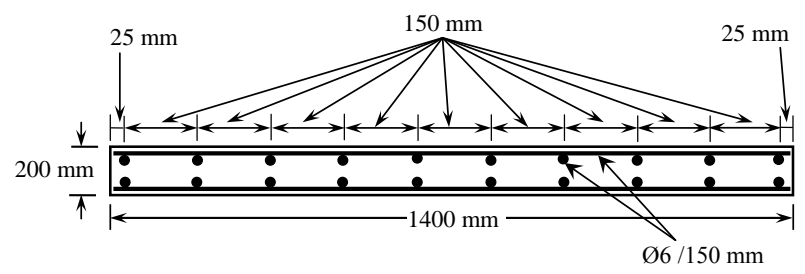

Fig. 2. Plan view of the reinforcement layouts of the shear-wall test specimen (SW1).

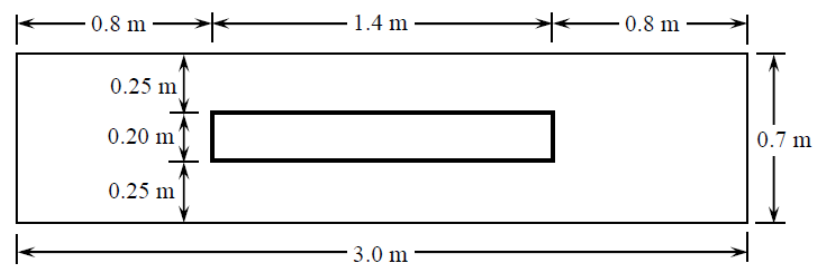

Fig. 3. Plan view of the test specimen (SW1) and the foundation, units are in meters.

The SW1 was constructed with normal-strength concrete having a nominal compressive strength $f_{c}=25 \mathrm{Mpa}$ and a weldable-grade reinforcing steel with a nominal $f_{y}$ of $500 \mathrm{Mpa}$ and $f_{u}$ of $550 \mathrm{MPa}$. Shear-wall thickness was $200 \mathrm{~mm}$. Mesh reinforcement for the walls consisted of $6 \mathrm{~mm}$ deformed bars. Double-layer mesh reinforcement was placed in the shear walls. Bar spacing in the vertical and horizontal directions were $150 \mathrm{~mm}$. The ratio of wall reinforcement along each orthogonal direction was 0.0020 . The amount of reinforcement used in the walls corresponded to minimum vertical and horizontal reinforcement ratio (i.e., ratio of reinforcement area to gross concrete area) requirement $\left(\rho_{s v}\right.$, $\rho_{s h}=0.002$ ) of the regulatory seismic design code in Turkey [10]. Shear wall test specimen was monotonically constructed and manufactured on the foundation having $0.7 \mathrm{~m}$ width, $3.0 \mathrm{~m}$ length, and $0.5 \mathrm{~m}$ thickness. The rigid foundation was clamped to the laboratory strong floor by high-strength steel bolts. Fig. 2 shows the plan view of the reinforcement layouts of the shear-wall test specimen SW1. Plan view of the test specimen SW1 and the foundation is presented in Fig. 3. The photographs in Fig. 4, Fig. 5 and Fig. 6 show construction stage of the shear wall test specimen SW1. Fig. 4 shows the front view of the test specimen SW1 in the construction stage. Top view of the test specimen SW1 in the construction stage is shown in Fig. 5. Fig. 6 shows the pouring the concrete of the test specimen SW1.

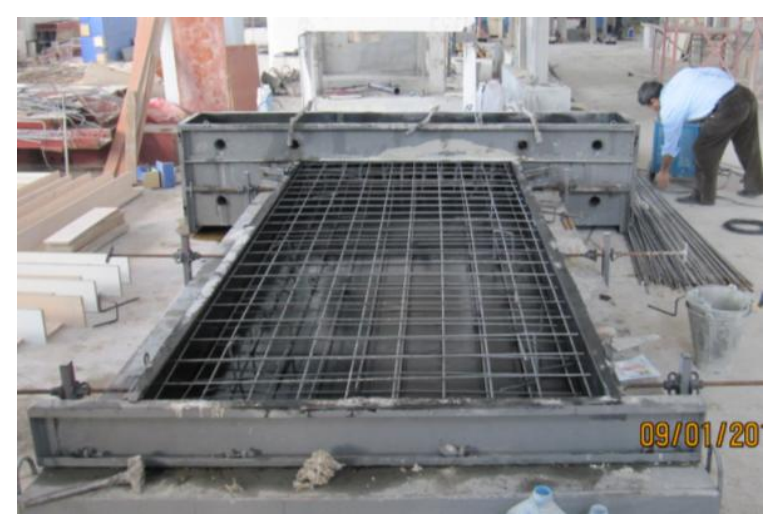

Fig. 4. Front view of the test specimen (SW1) in the construction stage.

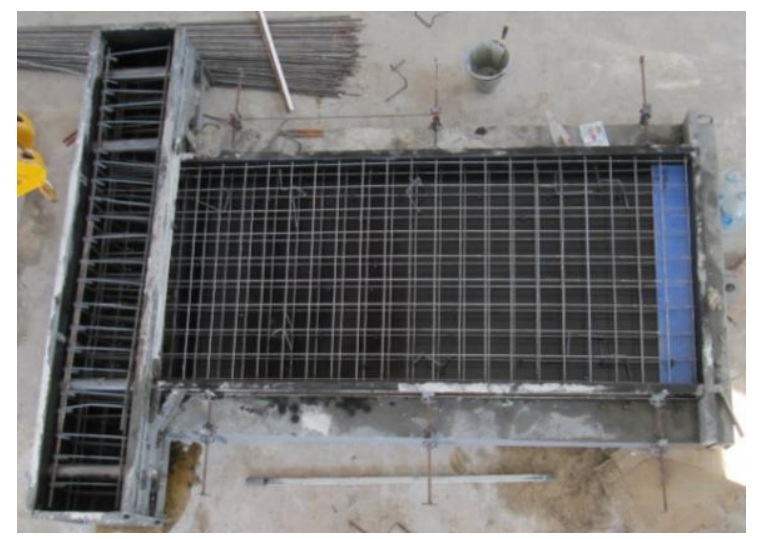

Fig. 5. Top view of the test specimen (SW1) in the construction stage.

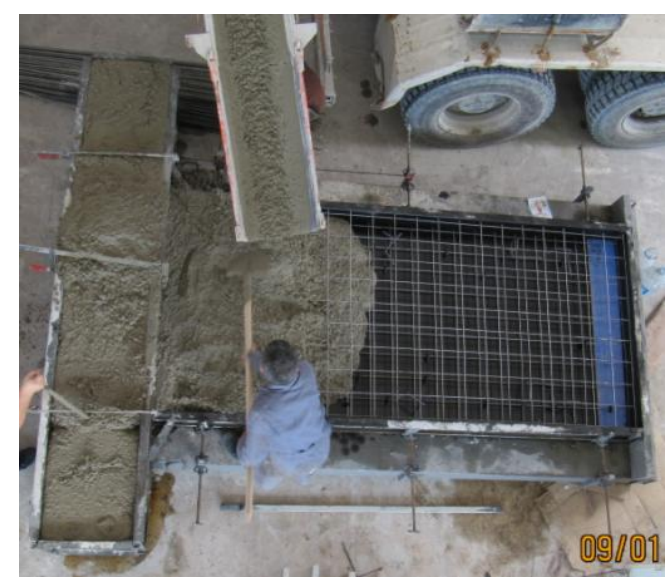

Fig. 6. Pouring the concrete of the test specimen (SW1).

\section{INSTRUMENTATION AND TEST PROCEDURE}

The testing was performed to determine the inelastic seismic behavior of the rectangular shear wall specimen. The specimen included the test wall portion and a strong foundation block used to reproduce realistic base condition. The foundation block was purposely designed significantly 
thicker than the test wall to limit cracking in the foundation. The wall and foundation portions were cast continuously without cold joints. The concrete of the wall was supplied by a local supplier with a specified $f_{c}{ }^{\prime}$ of $25 \mathrm{MPa}$. The specimen was mounted vertically on the strong floor of the laboratory and the load was applied by a $500 \mathrm{kN}$ actuator with pinned end conditions.

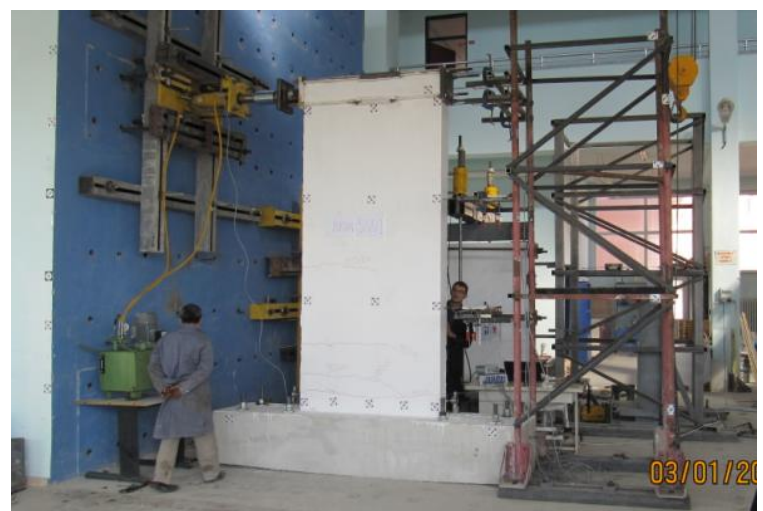

Fig. 7. Test setup, loading system and instrumentation of SW1.

Fig. 7 shows the test setup used in the experimental program. The testing system consisted of strong floor, reaction wall, loading equipment, instrumentation and data acquisition system. The lateral loading system consisted of a load cell, hydraulic jack and hinge. Instruments were used to measure loads and displacements for the specimen. Load cell measured the lateral loads applied to the specimen. Strain gage-based linear variable differential transformers (LVDTs) and dial gages (DGs) were used to measure the displacements. Five linear variable differential transformers (LVDTs) were mounted to measure the lateral displacements over the wall height. An LVDT was mounted horizontally on the foundation to monitor any horizontal slip of the foundation along the reaction floor.

Test was conducted by controlling the horizontal top displacement imposed by the actuator. The specimen was subjected to monotonic lateral loading. The measurements were recorded by a computer data acquisition system. During the tests, cracks and failures were observed carefully and recorded by hand. Movements of the foundation block and actuator resisting system was monitored and removed to obtained the wall deformations relative to the foundation. In this monotonic test, the lateral displacement was imposed at a constant rate of $1.0 \mathrm{~mm} / \mathrm{minute}(0.04 \mathrm{in} . / \mathrm{minute})$. The test, however, was interrupted to allow for observation of damage and photos to be taken.

\section{EXPERIMENTAL RESULTS}

As it is known the behavior of reinforced concrete in bending is nonlinear. The nonlinearity is due to the nonlinear behavior of the concrete. The performed test showed an expected flexure-dominant behavior in accordance with the design process, without the crushing of the compressed concrete and the tearing of the tensioned steel reinforcement. Fig. 8 shows the cracking patterns of SW1 at $40 \mathrm{kN}$ lateral load level. Fig. 9 shows the cracking patterns of SW1 at $100 \mathrm{kN}$ lateral load level. Fig. 10 shows the general view of specimens at failure stage. Cracking patterns of wall specimen (SW1) after test is given Fig. 11.

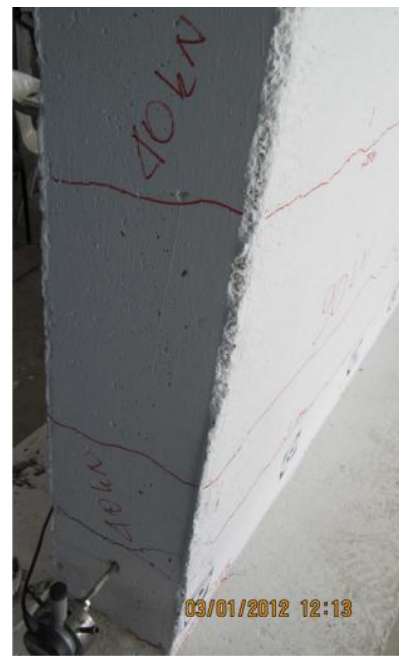

Fig. 8. Cracking patterns of SW1 at 40kN lateral load level.

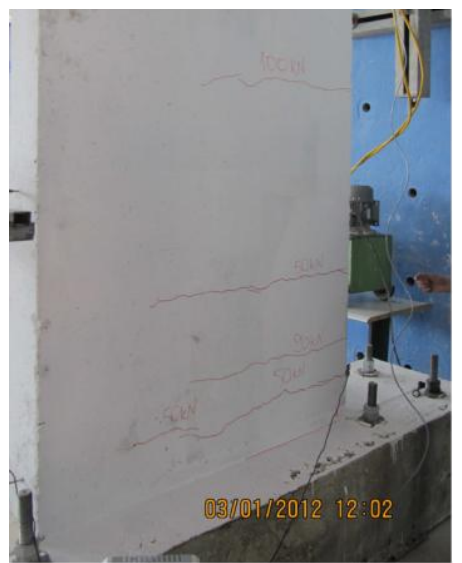

Fig. 9. Cracking patterns of SW1 at 100kN lateral load level.

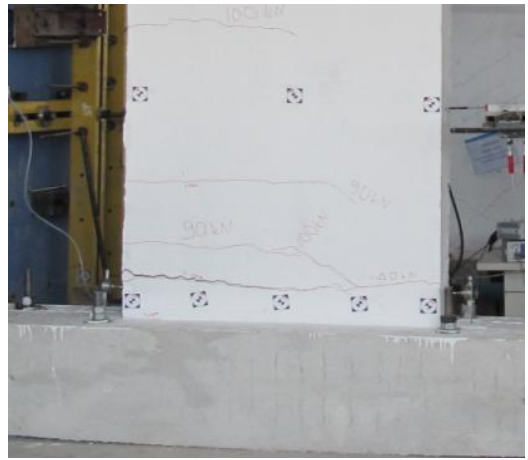

Fig. 10. General view of specimens at failure stage.

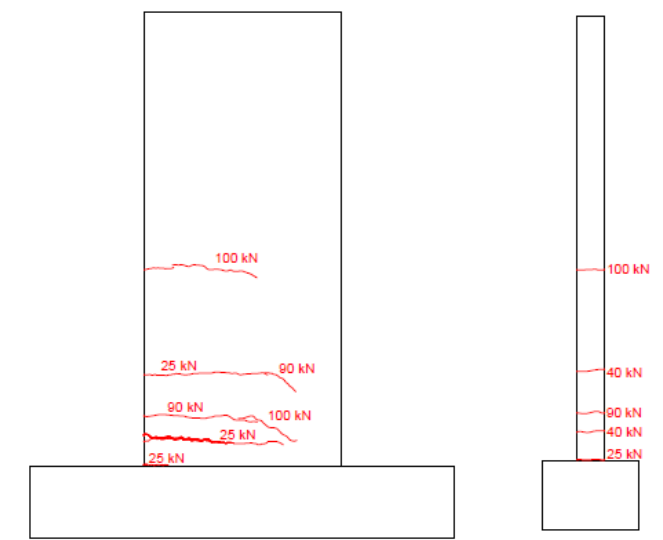

Fig. 11. Cracking patterns of wall specimen (SW1) after test. 


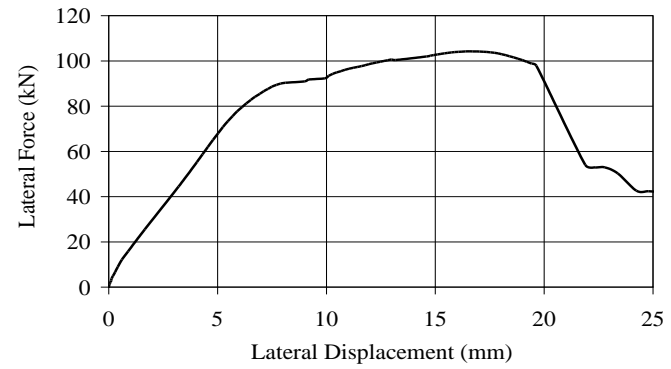

Fig. 12. Lateral force versus lateral top displacement relationships.

Fig. 12 shows the lateral force versus lateral top displacement relationships. Lateral force versus lateral top drift ratio is given in Fig. 13. For the shear wall test specimen SW1, the mode of the failure was brittle. The crushing of concrete was not observed. This failure mechanism occurred due to low longitudinal reinforcement ratio of walls and negative contribution of low axial load, section cracked as a consequence of tensile forces acting opposite direction of lateral load. In other words, low axial load has less contribution in retarding the tensile stress initiation. As soon as the tensile stress in the concrete exceeded the modulus of rupture (tensile strength), the cracking took place and the concrete immediately released the tensile force it carried. Then, the lightly stressed steel absorbed this increment of load For the shear wall specimen (SW1), the minimum amount of longitudinal steel was unable to carry the additional load, therefore following the cracking of concrete, longitudinal reinforcements yielded and ruptured suddenly without warning.

The crushing of concrete was not observed and the damage was concentrated on the lower part of the shear-wall. This failure mechanism occurred due to low longitudinal reinforcement ratio of walls and negative contribution of low axial load. In other words, low axial load has less contribution in retarding the tensile stress initiation.

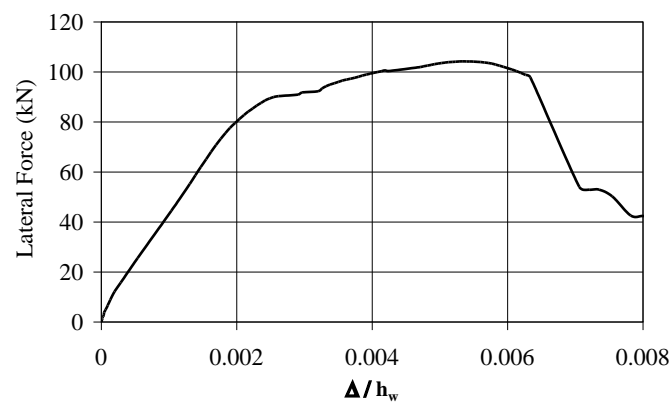

Fig. 13. Lateral force versus lateral top drift ratio.

\section{CONCLUSION}

The experimental results showed that lightly reinforced structural walls of tunnel-form buildings with low axial stress may exhibit brittle flexural failure under lateral loading. The brittle failure takes place due to rupture in longitudinal reinforcement with no crushing of concrete. If the shear wall with very low axial load ratio is lightly reinforced with a small percentage of steel, the failure mode becomes brittle. When the tensile stress in the concrete exceeds the modulus of rupture (tensile strength), the concrete cracks and immediately releases the tensile force it carries; the lightly stressed steel should then absorb the additional load. If the area of the provided steel is too small to carry this extra force, the steel snaps and total rupture of the section occurs suddenly. It is therefore essential to have sufficient tensile reinforcement so that the moment capacity after cracking exceeds the cracking moment.

\section{REFERENCES}

[1] E. Kalkan and S. B. Yuksel, "Prons and cons of multi-story rc tunnel form buildings," The Structural Design of Tall and Special Buildings, vol. 17, no. 3, pp. 601-617, 2008.

[2] S. B. Yüksel, "Behaviour of coupling beams having vertical slits at the ends," in Proc. International Conf. on Earthquake Resistant Engineering Structures VI, Bologna, Italy, 2007, vol. 93, pp. 53-62.

[3] S. B. Yüksel and E. Kalkan "Failure mechanisms of shear-wall dominant multi-story buildings," in Proc. $4^{\text {th }}$ International Conf. on High Performance Structures and Materials IV, Algarve Portugal, 2008, vol. 97, pp. 337-346.

[4] S. B. Yuksel and E. Kalkan, "Behavior of tunnel form, and buildings under quasi-static cyclic lateral loading," Structural Engineering \& Mechanics, vol. 27, no. 1, pp. 99-115, 2007.

[5] S. B. Yuksel, "Slit connected coupling beams for tunnel form building structures," The Structural Design of Tall and Special Buildings, vol. 13, no. 3, pp. 579-600, 2008.

[6] C. Balkaya, S. B. Yuksel, and O. Derinoz, "Soil-structure interaction effects on the fundamental periods of the shear-wall dominant buildings," The Structural Design of Tall and Special Buildings, vol. 21, no. 6, pp. 416-430, 2012.

[7] S. B. Yüksel, "Modeling and simulation of shear walls using moment-curvature analysis," in Proc. International Conf. on Modeling and Simulation (AMSE), Konya, August 28-30, 2006, vol. 1, pp. 463-468.

[8] S. B. Yuksel, "A moment-curvature program for structural walls," Journal of the Engineering and Architecture Faculty of Selçuk University, vol. 18, no. 1, pp. 75-84, 2003.

[9] S. B. Yuksel, "Ductility of symmetrically flanged shear walls," in Proc. First European Conf. on Earthquake Engineering and Seismology (a joint event of the 13th ECEE \& 30th General Assembly of the ESC), Geneva, Switzerland, September 3-8, 2006, Paper no. 545.

[10] Specifications for the Structures to Be Built in Disaster Regions, Ministry of Public Work and Settlement, Ankara, Turkey, 1975.

[11] S. B. Yuksel, "Tünel kalıp binaların dikdörtgen kesitli perde duvarlarının deprem güvenliği (Earthquake safety of the tunnel-form building shear walls having rectangular cross sections )," Selcuk University BAP project number: 11401018, Konya, Turkey, 2012.



Bahadır Yüksel was born in 1971. He is with the Department of Civil Engineering, Engineering Faculty, Selcuk University, Konya, 42075, Turkey. He took his M.s. and Ph.D. degrees from the Middle East Technical University. 